\title{
Charcot-Marie-Tooth disease type 4B3
}

INSERM

\section{Source}

INSERM. (1999). Orphanet: an online rare disease and orphan drug data base. CharcotMarie-Tooth disease type 4B3. ORPHA:363981

Charcot-Marie-T ooth disease type 4B3 (CMT 4B3) is a subtype of Charcot-Marie-Tooth type 4 characterized by a childhood onset of slowly progressing, demyelinating sensorimotor neuropathy, focally folded myelin sheaths in nerve biopsy, reduced nerve conduction velocities (less than $38 \mathrm{~m} / \mathrm{s}$ ), and the typical CMT phenotype (i.e. distal muscle weakness and atrophy, and sensory loss). 